\title{
MODEL PEMBELAJARAN THINK PAIR SHARE SEBAGAI UPAYA MENINGKATKAN HASIL BELAJAR MATEMATIKA
}

\author{
Joko Budiharjo \\ SMP Negeri 5 Sukoharjo \\ E-mail: jokobudiharjo05@gmail.com
}

\begin{abstract}
Abstrak
Penelitian ini bertujuan untuk meningkatkan hasil belajar matematika materi Persamaan Linear dua Variabel siswa melalui model pembelajaran kooperatif tipe think pair share pada siswa kelas VIII H SMP Negeri 5 Sukoharjo semester I tahun pelajaran 2017/ 2018. Penelitian ini adalah Penelitian Tindakan Kelas yang dilakukan di kelas VIII H SMP Negeri 5 Sukoharjo semester I tahun pelajaran 2017/ 2018 yang berjumah 32 siswa. Teknik pengumpulan data yang digunakan adalah tes, observasi, dan dokumentasi.Tahaptahap analisis data dalam penelitian ini adalah pengumpulan data, reduksi data, penyajian data, dan penarikan kesimpulan. Indikator keberhasilan adalah nilai rata-rata tes siswa sekurang-kurangnya 80,0 dan banyak siswa dengan nilai di atas kriteria ketuntasan minimal (KKM) yaitu70,0 mencapai $\geq 93 \%$.Berdasarkan penelitian yang telah dilakukan, dapat disimpulkan bahwa penerapan model pembelajaran kooperatif tipe think pair share dapat meningkatkan hasil belajar matematika materi Persamaan Linear dua Variabel siswa kelas VIII H SMP Negeri 5 Sukoharjo. Sebelum tindakan/prasiklus,hasil belajar siswa yang mencapai KKM 19 siswa atau 59,37\%, pada siklus I, 23 siswa atau 71,87\% dan pada siklus II, 30 siswa atau $93,75 \%$. Nilai rata-rata kelas sebelum tindakan/prasiklus sebesar 69,69 setelah tindakan siklus I sebesar 72,0 dan setelah tindakan siklus II sebesar 81,87 .
\end{abstract}

Kata Kunci: Model pembelajaran think pair share, hasil belajar matematika

\begin{abstract}
This study aims to improve the learning outcomes of the matematics material Two Variable Linear Equal learning model type Think pair share in students of class VIII H SMP Negeri 5 Sukoharjo first semester academic year 2017/2018. This research is a Classroom Action Research conducted in class VIII H SMP Negeri 5 Sukoharjo first semester of academic year 2017/ 2018 with 32 students. Data collection techniques used are tests, observations, and documentation. The stages of data analysis in this study are data collection, data reduction, data presentation, and conclusion. The success indicator is the average score of the student's test at least 80,0 and many students with a value above the minimum mastery criteria $(\mathrm{KKM})$ of 70,0 reach $\geq 93 \%$.Based on the research that has been done, it can be concluded that the application of cooperative learning model type Think pair share can improve learning result of matematics material of Two Variable Linear Equal letters student of class VIII H SMP Negeri 5 Sukoharjo . Before the action / pre cycle, student learning outcomes reaching KKM 19 students or 59,37\%, in cycle I, 23 students or $71,87 \%$ and in cycle II, 30 students or $93,75 \%$. The average value of the class before the action/ pre cycle was $71,87 \%$ after the first cycle action was 72,0 and after the
\end{abstract}


second cycle action was 81,87

Keyword: Think pair share model, learning result mathematics

\section{PENDAHULUAN}

Banyak siswa yang sulit dalam memahami penjelasan yang disampaikan oleh guru matematika, membuat siswa acuh dan bahkan tidak mau memperhatikan pelajaran. Pembelajaran matematika tidaklah sulit untuk dapat dipelajrai, dengan menggunakan model yang tepat akan membuat siswa mudah dalam memahami materi yang disampaikan oleh guru, siswa juga tidak mudah bosan, dan dengan adanya media pembelajaran juga turut membantu siswa dalam memahami materi yang disampaikan.

Berdasarkan hasil pengamatan penulis dengan teman sejawat di SMP Negeri 5 Sukoharjo, masalah yang dihadapi siswa adalah masih rendahnya hasil belajar matematika yang dimiliki oleh siswa. Hal ini disebabkan oleh siswa yang kurang aktif dalam pembelajaran berlangsung, siswa yang tidak mau berpirik dalam menyelesaikan soal, siswa yang kurang lancar dalam berbicara matematika, karena siswa kurang latihan mengerjakan soal. Rendahnya hasil belajar siswa dapat dilihat dari hasil nilai matematika yang kebanyakan masih di bawah standart ketuntasan belajar yaitu 70,00. Selain itu penulis juga mendapatkan informasi dari siswa di SMP Negeri 5 Sukoharjo, bahwa metode yang digunakan oleh guru yaitu ceramah, diskusi, dan penugasan juga membuat siswa bosan pada saat mengikuti pembelajaran. Ini membuat siswa menjadi pasif, ada juga takut pada saat mengikuti pembelajaran, dan membuat hasil belajar siswa menurun. Tidak tercapainya nilai KKM yang telah ditetapkan oleh sekolah yaitu 70,00. Di dalam kelas VIII H terdapat 32 siswa, sedangkan siswa yang tuntas didalam 1 kelas hanya ada sekitar 19 siswa, dan sebagian besar siswa masih banyak yang sulit dalam memahami penjelasan materi dari guru, dapat dikatakan siswa yang masih belum tuntas memiliki persentase $40,63 \%$, sedangkan siswa yang sudah tuntas ada $59,37 \%$.

Salah satu model pembelajaran yang dapat digunakan dalam proses pembelajaran adalah model pembelajaran kooperatif tipe think pair share. 
Dimana model ini dikembangkan untuk mencapai hasil belajar yang berupa prestasi akademik, toleransi, keragaman dan perkembangan keterampilan sosial. Dengan model ini diharapkan siswa akan lebih aktif dalam bertanya dan dalam penyampaian pendapat, siswa juga diharapkan akan lebih dapat bersosialisasi dengan teman meraka dan dapat mengumpulkan banyak informasi tentang materi pembelajaran yang belum mereka ketahui sebelumnya. Selain itu, model pembelajaran kooperatif tipe think pair share ini juga memiliki kelebihan karena pembelajaran disusun dalam bentuk kelompok. Sehingga model ini dianggap sebagai model yang dapat meningkatkan prestasi belajar matematika siswa. Namun perlu diadakan penelitian untuk dapat menyimpulkan bahwa model think pair share dapat meningkatkan prestasi belajar siswa terutama dalam pembelajaran matematika.

Menurut pendapat dari beberapa ahli tentang pembelajaran kooperatif tipe think pair share sebagai berikut: (1) Dalam Siti F (2009: 10 Februari 2012), model pembelajaran kooperatif tipe think pair share merupakan salah satu tipe pembelajaran kooperatif yang dikembangkan oleh Frank Lyman, dkk dari Universitas Maryland pada tahun 1985 sebagai salah satu struktur kegiatan cooperative learning. Think pair share memberikan waktu kepada para siswa untuk berpikir dan merespon serta saling bantu satu sama lain. Think pair share memberi siswa kesempatan untuk bekerja sendiri serta bekerja sama dengan orang lain; (2) Pembelajaran kooperatif TPS (Huda, 2011: 136) dalam cooperative lerning metode, teknik, struktur dan model penerapan, memungkinkan siswa untuk bekerja sendiri dan bekerja sama dengan orang lain sehingga bisa mengoptimalkan partisipasi siswa; (3) Pembelajaran kooperatif tipe think pair share merupakan salah satu tipe pembelajaran kooperatif yang merupakan metode pembelajaran dengan membentuk kelompok-kelompok kecil yang juga bertujuan untuk berinteraksi antar siswa, yang mengajarkan kepada siswa bahwa untuk mencapai sesuatu tidak dapat dicapai secara sendiri, melainkan dikerjakan bersama-sama. Mengajarkan kepada siswa untuk dapat berinteraksi dan bergaul dengan siswa yang lain tanpa membedakan ras, suku, dan agama. Pembelajaran kooperatif tipe think pair share ini membagi siswa menjadi beberapa kelompok 
yaitu kelompok 1 sampai kelompok 8, yang masing-masing kelompok mengerjakan tugasnya sendiri-sendiri.

Siswa diajarkan untuk belajar bersama dengan siswa yang lain, saling bertukar informasi yang mereka miliki, dan mengajarkan sportifitas dalam kegiatan kelompok terebut. Pembelajaran kooperatif tipe think pair share ini adalah variasi dalam kegiatan kelompok yang sebelumnya pernah ada, dengan penggunaan metode ini diharapkan siswa dapat lebih aktif didalam menerima pembelajaran dan diharapkan siswa tidak bosan dan lebih mudah dalam menerima penjelasan yang diterangkan oleh guru yang membuat peningkatan prestasi belajar siswa terutama pada pembelajaran matematika.

Langkah-langkah kegiatannya adalah sebagai berikut : (1) Guru membagi siswa dibagi dalam beberapa kelompok, setiap kelompok terdiri dari 4 siswa yang masing-masing dalam kelompok memiliki peran yang sama yaitu mengerjakan soal yang diberikan guru; (2) Guru menyiapkan Siswa untuk mempelajari materi pelajaran yang telah diberikan dengan satu kelompoknya dan membantu teman satu kelompok apabila ada yang kurang memahami materi yang dipelajari; (3) Setiap siswa memikirkan jawaban soal masing-masing; (4) Kemudian setiap siswa mendiskusikan jawaban dalam satu kelompok; (5) Setiap kelompok mempresentasikan jawaban didepan kelas yang jawabannya benar akan diberikan tambahan poin oleh guru; (6) Setelah satu babak kemudian soal pertanyaan diputar lagi agar tiap kelompok mendapat soal yang berbeda dari soal sebelumnya, demikian seterusnya.Kemudian diakhir kegiatan guru bersama-sama dengan siswa menyimpulkan dari materi yang telah dipelajari.

Alternatif yang dapat ditempuh dalam meningkatkan hasil belajar siswa adalah melalui kreatifitas guru dalam memilih model pembelajaran.Pemilihan model pembelajaran yang tepat dan bervariasi dapat meningkatkan hasil belajar siswa terutama dalam mata pelajaran matematika. Karena tidak semua model cocok digunakan dalam penyampaian materi, kreativitas guru sangatlah diperlukan dalam pemilihan model pembelajaran yang akan digunakan. Dengan menggunakan model pembelajarana yang tepat dan bervariasi dalam penyampaian materi dapat membantu siswa untuk meningkatkan ide, gagasan dan kreativitas 
yang dimiliki siswa. Peran guru sebagai fasilitator sangatlah membantu siswa mengembangkan kreativitas yang mereka miliki, siswa juga akan dituntut untuk aktif dalam proses pembelajaran, ini membuat siswa menjadi lebih bersemangat dan bertanggung jawab dalam menemukan hasil jawaban yang diberikan kepada siswa. Pembentukan kelompok juga sangat berguna dalam meningkatkan hasil belajar siswa terutama pada mata pelajaran matematika, siswa juga akan belajar untuk bersosialisasi dengan teman yang lain, dengan demikian akan menjalin kekompakan dan kerja sama dalam menemukan solusi dari masalah yang diberikan kepada siswa. Pembentukan kelompok akan membuat siswa menjadi senang dalam mengikuti pembelajaran dan tujuan yang didasarkan pada alasan bahwa untuk mencapai sesuatu tidak dapat dicapai secara sendiri, melainkan harus dikerjakan secara bersama-sama, hal ini akan meningkatkan kekompakan, keaktifan, serta kerja sama. Siswa memungkinkan dapat meraih keberhasilan dalam belajar, di samping itu juga akan melatih siswa untuk meningkatkan keterampilan berpikir, dan keterampilan sosial seperti mengemukakan pendapat, menerima saran, bekerja sama dan rasa setia kawanan.

Berdasarkan latar belakang di atas, maka dapat dirumuskan masalah, “Apakah dengan menerapkan model pembelajaran kooperatif tipe think pair share dapat meningkatkan hasil belajar materi Persamaan Linear Dua Variabel pada siswa kelas VIII H SMP Negeri 5 Sukoharjo semester I tahun pelajaran 2017/ 2018?".

\section{METODE PENELITIAN}

Penelitian ini adalah Penelitian Tindakan Kelas. Penelitian tindakan kelas merupakan suatu pencermatan terhadap kegiatan yang sengaja dimunculkan, dan terjadi dalam sebuah kelas (Arikunto, 2010: 130). Penelitian ini dilaksanakan di SMP Negeri 5 Sukoharjo.Tahap-tahap pelaksanaan kegiatan dilakukan selama kurang lebih enam bulan yaitu sejak bulan Juli sampai dengan Desember 2017. Peneliti sebagai guru SMP Negeri 5 Sukoharjo bertindak sebagai subjek yang melakukan tindakan kelas.Teman sejawat sesama guru mata pelajaran matematika sebagai observer. Kepala Sekolah bertindak sebagai subjek yang membantu dalam 
perencanaan dan pengumpulan data. Subjek yang menerima tindakan adalah siswa kelas VIII H SMP Negeri 5 Sukoharjo semester I tahun pelajaran 2017/2018 sebanyak 32 siswa.

Teknik pengumpulan data yang digunakan adalah: tes, observasi dan dokumentasi. Tes adalah serentetan pertanyaan atau latihan serta alat lain yang digunakan untuk mengukur keterampilan, pengetahuan inteligensi, kemampuan atau bakat yang dimiliki oleh individu dan kelompok (Arikunto, 2010 : 193).

Tes digunakan adalah jenis tes hasil (achievement test) berupa kuis individu.Tes ini digunakan untuk mengukur pencapaian siswa setelah mempelajari materi. Hal ini dapat juga sebagai alat untuk mengetahui tingkat pemahaman siswa setelah mempelajari materi Persamaan Linear Dua Variabel dengan menggunakan model pembelajaran kooperatif tipe think pair share. Tes tertulis adalah suatu teknik penilaian yang menunutut jawaban secara tertulis, baik berupa pilihan atau isian. Tes yang jawabannya berupa pilihan meliputi pilihan ganda, benar salah dan menjodohkan, sedangkan tes yang jawabannya berupa isian berbentuk isian singkat atau uraian (Suprijono, 2013:138).

Observasi atau pengamatan dilakukan guna memperoleh data yang akurat, dengan menggunakan lembar observasi. Lembar observasi digunakan untuk memonitor dan mengevaluasi setiap tindakan agar kegiatan observasi tidak terlepas dari konteks permasalahan dan tujuan penelitian. Observasi yang digunakan adalah observasi sistematis, yaitu observasi yang dilakukan oleh pengamat dengan menggunakan pedoman sebagai instrumen pengamatan dan observasi non-sistematis yang dilakukan dengan tidak menggunakan instrumen pengamatan. Dokumentasi diperoleh dari hasil kuis siswa, lembar observasi, lembar wawancara, catatan lapangan, daftar siswa, dan foto-foto selama proses kegiatan belajar mengajar. Dokumentasi ini dimaksudkan adalah sebagai buktibukti konkret dari penelitian tindakan kelas tersebut.

Instrumen yang digunakan dalam penelitian berupa tes, lembar observasi dan lembar dokumentasi. Tes berbentuk tes tertulis yang dilakukan dalam post test dan kuis individu. Tes ini digunakan untuk mengetahui sejauh mana peningkatan hasil belajar siswa dengan penerapan model pembelajaran kooperatif tipe think 
pair share. Lembar Observasi, digunakan lembar observasi hasil belajar siswa dan lembar observasi pelaksanaan pembelajaran kooperatif. Lembar observasi digunakan pada setiap pembelajaran sehingga kegiatan observasi tidak terlepas dari konteks permasalahan dan tujuan penelitian, untuk lembar hasil belajar siswa digunakan pada saat siswa dapat menyelesaikan permasalahan dengan kegiatan belajar mengajar dan sedangkan lembar observasi pelaksanaan kegiatan belajar mengajar dengan model pembelajaran Kooperatif Tipe think pair share digunakan sebagai pedoman peneliti dalam melakukan observasi pelaksanaan kegiatan belajar mengajar dengan menggunakan model pembelajaran kooperatif tipe think pair share. Lembar dokumentasi ini bertujuan untuk mengetahui data siswa selama kegiatan penelitian berlangsung.Lembar dokumentasi ini berupa, foto-foto kegiatan pembelajaran, daftar hadir kegiatan pembelajaran, daftar hadir, daftar nilai, dan sebagainya.

Indikator keberhasilan kinerja dalam penelitian ini adalah meningkatnya hasil belajar matematika materi Persamaan Linear Dua Variabel siswa, yang ditunjukkan dengan meningkatnya nilai rata-rata tes siswa sekurang-kurangnya 80,0 dan banyak siswa dengan nilai di atas kriteria ketuntasan minimal (KKM) yaitu $\geq 70,0$ mencapai $\geq 93 \%$.

\section{HASIL PENELITIAN DAN PEMBAHASAN}

\section{a. Hasil Penelitian}

Deskripsi data hasil penelitian yang telah dilakukan di kelas VIII H SMP Negeri 5 Sukoharjo adalah sebagai berikut. Berdasarkan observasi awal di kelas VIII H mata pelajaran matematika dengan materi Persamaan Linear dua Variabel diperoleh data, dari 32 siswa yang mencapai nilai kriteria ketuntasan minimal (KKM) sebanyak 19 siswa (59,37\%), dengan nilai rata-rata kelas sebesar 69,69. Penelitian ini dilakukan dengan indikator kinerja nilai rata-rata tes siswa sekurang-kurangnya 80,0 dan banyak siswa dengan nilai di atas kriteria ketuntasan minimal $(\mathrm{KKM})$ yaitu $\geq 70,0$ mencapai $\geq 59,37 \%$. 
Kemudian peneliti merencanakan observasi survai berikutnya untuk mengetahui kebenarannya.Pada kegiatan survei awal yang dilaksanakan pada hari Rabu, 10 Agustus 2017. Hasil observasi awal menunjukkan bahwa guru yang mendominasi kegiatan pembelajaran dan siswa cenderung tidak aktif. Salah satu solusi yang dikembangkan adalah penggunaan model pembelajaran yang baru yaitu dengan Model Pembelajaran Kooperatif Tipe think pair share. Dengan penggunaan model pembelajaran tersebut diharapkan akan menciptakan suasana belajar yang berbeda, bervariasi dan menyenangkan sehingga dapat menarikperhatian siswa, meningkatkan keaktifan siswa yang muara akhirnya meningkatkan hasil belajar siswa.

Tindakan kelas siklus I dilaksanakan pada hari Rabu, 10 Agustus 2017 di SMP Negeri 5 Sukoharjo kelas VIII H. Setelah langkah apersepsi dilanjutkan dengan penyampaian materi dengan model pembelajaran kooperatif tipe think pair share .

Berdasarkan hasil evaluasi pada siklus I menunjukkan adanya peningkatan hasil belajar siswa. Hasil belajar siswa sebanyak 23 mencapai nilai kriteria ketuntasan minimal (KKM) atau 71,87\%, rata-rata kelas naik menjadi 72,0. Berdasarkan pengamatan tersebut dapat diketahui bahwa proses pembelajaran pada siklus pertama belum berhasilmaksimaldan belum mencapai indikator kinerja yang diharapkan. Peningkatan hasil, jika dibandingkan hasil prasiklus yang mencapai KKM sebanyak 19 siswa atau 59,38\% setelah diberi tindakan penerapan siklus I, siswa yang mencapai KKM sebanyak 23 siswa atau 71,87\%.

Tabel 1.Perkembangan Siswa yang Mencapai KKM Sebelum Tindakan/Prasiklus ke Siklus I

\begin{tabular}{ccc}
\hline Hasil Siswa & Prasiklus & Siklus I \\
\hline Siswa mencapai KKM & 19 & 23 \\
\hline
\end{tabular}

Berdasarkan tabel 1 di atas dapat disimpulkan bahwa hasil belajar matematika materi Persamaan Linear dua Variabel siswa dengan menerapkan model pembelajaran kooperatif tipe think pair share pada pelaksanaan tindakan siklus I mengalami peningkatan. Siswa yang mencapai KKM Sebelum dilakukan 
tindakan atau prasiklus 19 siswa, setelah tindakan siklus I sebanyak 23 siswa sehingga meningkat 4 siswa.

Setelah dievaluasi bersama dari pelaksanaan tindakan pada siklus I yang digunakan sebagai bagian pertimbangan perencanaan pembelajaran siklus berikutnya, dengan perencanaan perbaikan untuk mengatasi kekurangan dan kesalahan yang dilakukan pada siklus I. Tindakan kelas siklus II dilaksanakan pada hari Rabu, 5 September 2017. Berdasarkan pembelajaran secara keseluruhan pada tindakan kelas siklus II menunjukan adanya peningkatan yang signifikan. Hasil belajar siswa sebanyak 30 siswa $(93,75 \%)$ mencapai nilai kriteria ketuntasan minimal (KKM). Sehingga rata-rata nilai kelas VIII H naik menjadi 82,53.

Tabel 2. Perkembangan Siswa yang Mencapai KKM Siklus I ke Siklus II

\begin{tabular}{ccc}
\hline Hasil Siswa & Siklus I & Siklus II \\
\hline Siswa mencapai KKM & 23 & 30 \\
\hline
\end{tabular}

Dari tabel 2 di atas dapat disimpulkan bahwa hasil belajar Persamaan Linear dua Variabel siswa dengan menerapkan model pembelajaran kooperatif tipe think pair share, pada pelaksanaan tindakan siklus II mengalami peningkatan. Siswa yang mencapai KKM pada saat dilakukan tindakan siklus I sebanyak 23 siswa, setelah tidakan siklus II sebanyak 30 siswa sehingga meningkat 7 siswa. Berdasarkan hasil tersebut dapat diketahui bahwa proses pembelajaran sampai dengan pada siklus II berjalan dengan baik dan telah memenuhi indikator kinerja yang diharapkan.

Pada siklus I dan II dengan penerapan tindakan menggunakan model pembelajaran kooperatif tipe think pair share, sehingga siswa lebih antusias dengan perasaan senang dalam mengikuti kegiatan pembelajaran. Nilai rata-rata siswa sejak sebelum diadakan penelitian hingga setelah diadakan penenelitian sampai dengan siklus II, dapat dilihat pada tabel berikut:

Tabel 3. Perkembangan Siswa yang Mencapai KKM Sebelum Tindakan/Prasiklus,Siklus I dan Siklus II

\begin{tabular}{rccc} 
dan Siklus II & & & \\
\hline Hasil Siswa & Prasiklus & Siklus I & Siklus II \\
\hline Siswa mencapai KKM & 15 & 23 & 30 \\
\hline
\end{tabular}


Dari tabel 3 dapat disimpulkan bahwa hasil belajar materi Persamaan Linear dua Variabel siswa dengan menerapkan model pembelajaran kooperatif tipe think pair share, di setiap pelaksanaan tindakan, baik siklus I dan siklus II mengalami peningkatan, yaitu: siswa yang mencapai KKM Sebelum dilakukan tindakan atau prasiklus 15 siswa, setelah tidakan siklus I sebanyak 23 siswa dan setelah tindakan siklus II sebanya 30 siswa, sehingga peningkatan kumulatif dari sebelum tindakan/prasiklus sampai dengan siklus II sebesar 10 siswa.

Tabel 4. Perkembangan Persentase Siswa Mencapai KKM Sebelum Tindakan/Prasiklus, Siklus I dan Siklus II

\begin{tabular}{cccc}
\hline Hasil Siswa & Prasiklus & Siklus I & Siklus II \\
\hline Persentase Siswa Mencapai KKM & $59,38 \%$ & $71,87 \%$ & $93,75 \%$ \\
\hline
\end{tabular}

Dari tabel 4 di atas dapat disimpulkan bahwa hasil belajar Persamaan Linear dua Variabel siswa dengan menerapkan model pembelajaran kooperatif tipe think pair share, di setiap pelaksanaan tindakan mengalami peningkatan, yaitu: persentase siswa yang mencapai KKM Sebelum dilakukan tindakan atau prasiklus 59,38\%, setelah tidakan siklus I sebanyak 71,87\% dan setelah tindakan siklus II sebanya $93,75 \%$.

Tabel 5. Perkembangan Nilai Rata-rata KelasSebelum Tindakan/Prasiklus, Siklus I dan Siklus II

\begin{tabular}{cccc}
\hline Hasil Siswa & Prasiklus & Siklus I & Siklus II \\
\hline Nilai rata-rata & 69,69 & 72,0 & 81,87 \\
\hline
\end{tabular}

Dari tabel 5 di atas dapat disimpulkan bahwa hasil belajar materi Persamaan Linear dua Variabel siswa dengan menerapkan model pembelajaran kooperatif tipe think pair share, di setiap pelaksanaan tindakan mengalami peningkatan, yaitu: nilai rata-rata kelas sebelum dilakukan tindakan atau prasiklus adalah 69,69, setelah tidakan siklus I adalah 72,0 dan setelah tindakan siklus II adalah 81,87 sehingga dari kondisi awal sebelum tindakan/prasiklus sampai dengan tidakan pada siklus II terjadi peningkatan sebesar 13,5. Dari uraian di atas dapat disimpulkan bahwa model pembelajaran kooperatif tipe think pair share 
dapat meningkatkan hasil belajar materi Persamaan Linear dua Variabel siswa kelas VIII H SMP Negeri 5 Sukoharjo semester I tahun pelajaran 2017/2018.

\section{b. Pembahasan}

Hasil penelitian pada kondisi awal pelaksanaan siklus II diperoleh data yang dapat ditabulasikan sebagai berikut:

Tabel 6. Profil Kelas Sebelum dan Sesudah Tindakan Penelitian

\begin{tabular}{llccc}
\hline No & Hasil Siswa & Kondisi Awal & \multicolumn{1}{c}{ Siklus I } & \multicolumn{1}{c}{ Siklus II } \\
\hline 1 & Nilai rata-rata & 69,69 & 72,0 & 81,87 \\
\hline 2 & Siswa yang tuntas KKM & 11 siswa & 23 siswa & 30 siswa \\
& & $(59,3 \%)$ & $(71,87 \%)$ & $(93,75 \%)$ \\
\hline
\end{tabular}

Adapun grafik peningkatan rata-rata hasil belajar dan persentase ketuntasan dapat disajikan pada gambar berikut;

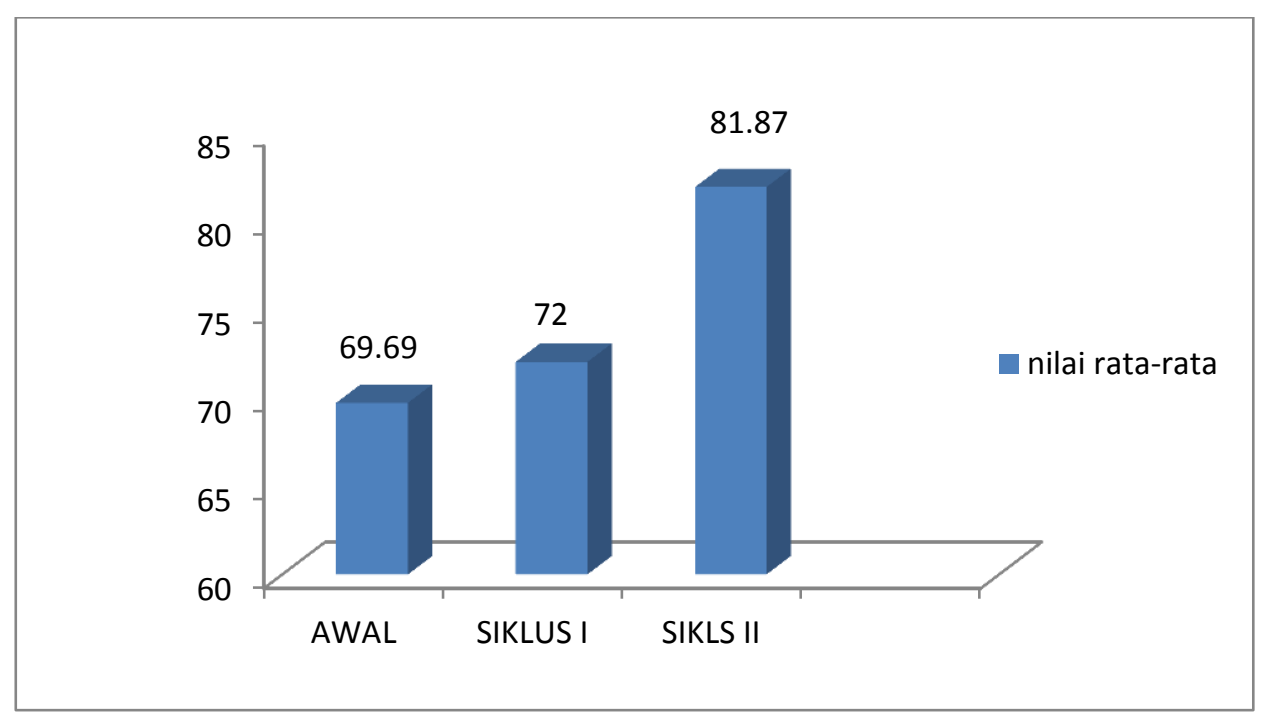

Gambar 1. Rata-rata Hasil Belajar Siswa pada Kondisi Awal, Siklus I, dan Siklus II 


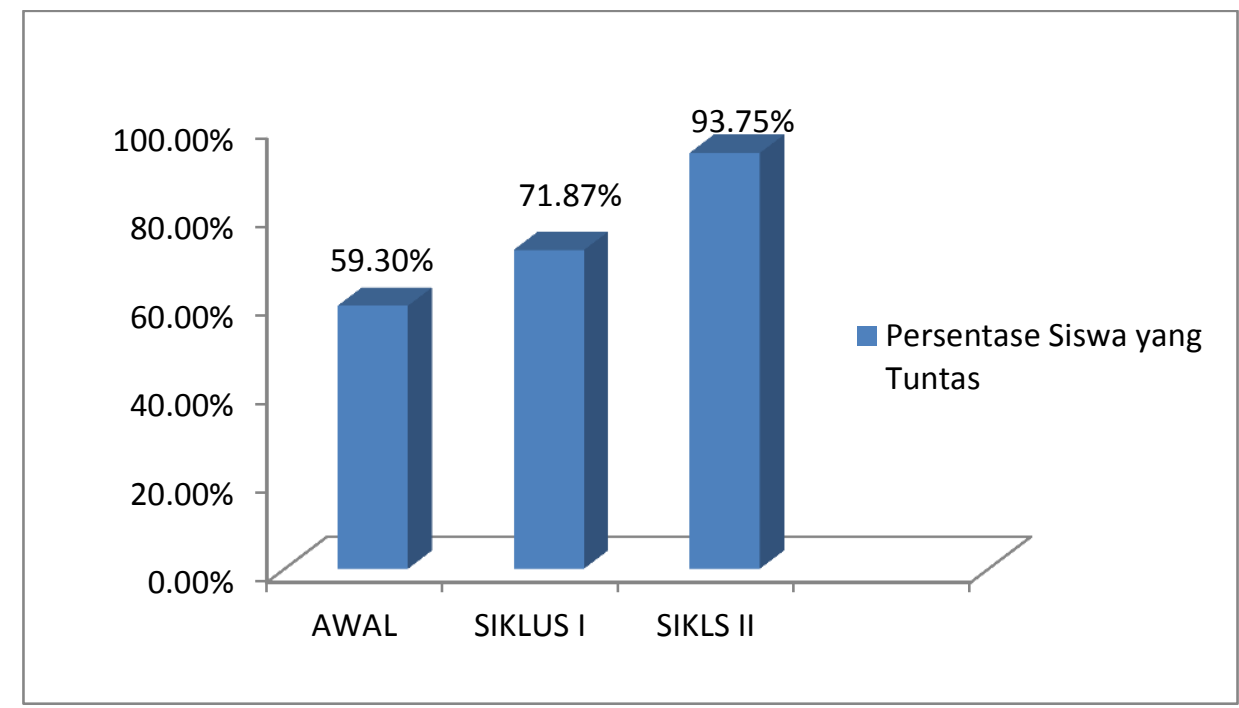

Gambar 2. Persentase Ketuntasan Siswa pada Kondisi Awal, Siklus I, dan Siklus II

Berdasarkan gambar 1 dan 2 dapat ditunjukkan bahwa prestasi belajar siswa dengan menerapkan pembelajaran model kooperatif tipe Think Pair Share di setiap putaran mengalami peningkatan, yaitu: (1) Sebelum dilakukan tindakan penelitian kelas nilai rata-rata hasil belajar siswa adalah 69,69 dengan presentase hasil belajar siswa hanya 59,3\%, (2) Setelah dilakukan tindakan pada siklus I nilai rata-rata hasil belajar siswa mengalami peningkatan yaitu 72,0 dengan presentase ketuntasan $71,87 \%$, tetapi belum mencapai indikator yang diharapkan; (3) Pada siklus II nilai rata-rata hasil belajar siswa meningkat yaitu menjadi 81,87 dengan presentase ketuntasan sebesar $93,75 \%$ dan sudah mencapai indikator yang diharapkan maka penelitian tindakan kelas ini sudah berhasil.

Rata-rata hasil belajar siswa pada kondisi awal 69,69 dengan persentase ketuntasan belajar siswa sebesar 59,3\%, pada siklus II naik menjadi $81,87 \geq 80,0$ (indikator kinerja) dengan presentase ketuntasan belajar siswa sebesar 93,75 $\geq$ $85 \%$ (indikator kinerja). Jadi, indikator kinerja sudah tercapai sehingga tidak dilanjutkan ke siklus berikutnya.

\section{SIMPULAN}

Berdasarkan hasil penelitian dapat disimpulkan, dengan penerapan model pembelajaran kooperatif tipe think pair share dapat meningkatkan hasil belajar 
materi Persamaan Linear dua Variabel siswa kelas VIII H SMP Negeri 5 Sukoharjo semester I tahun pelajaran 2017/ 2018.

Penelitian Tindakan Kelas (PTK) yang dilaksanakan di SMP Negeri 5 Sukoharjo ini sudah berjalan dengan cukup baik dan hasil yang baik pula. Namun masih banyak hal yang perlu diperbaiki. Oleh karena itu, peneliti memberikan beberapa saran. (1) Siswa diharapkan dapat lebih meningkatkan kemampuan diri melalui peran aktifnya dalam mengikuti kegiatan belajar mengajar. Peran aktif tersebut meliputi peran aktif dalam bertanya, mengemukakan pendapat maupun mempresentasikan gagasannya. (2) Guru matematika hendaknya dapat menumbuh kembangkan kreativitas dalam menjalankan profesinya sebagai fasilitator dan motivator dalam menyampaikan pembelajaran secara kreaktif dan inovatif pada siswa dalam penyampaian materi, sehingga siswa dapat menerima dan memahami materi yang diajarkan dengan baik. (3) Penelitian Tindakan Kelas (PTK) ini diharapkan akan membawa dampak positif terhadap perkembangan sekolah yang nampak pada peningkatan prestasi belajar siswa sehingga dapat meningkatkan prestasi dan kualitas sekolah.

\section{DAFTAR PUSTAKA}

Arikunto, S. 2006. Prosedur Penelitian Suatu Pendekatan Praktik. Jakarta: Rineka Cipta.

Aunurrahman. 2009. Belajar dan Pembelajaran. Bandung : Alfabeta.

Dimyati dan Mudjiono. 2009. Belajar dan Pembelajaran. Jakarta: Rineka Cipta.

Hamalik, Oemar. 2004. Proses Belajar Mengajar. Jakarta: Bumi Aksara.

Isjoni. 2007. Cooperative Learning Efektifitas Pembelajaran Kelompok. Bandung: Alfabeta.

Maretanika Puspitasari. 2015. Penggunaan Model Pembelajaran Kooperatif Tipe Think pair share untuk Meningkatkan Prestasi Belajar Matematika Pokok Bahasan Persamaan Kuadrat Siswa Kelas VIII B Sekolah Menengah Pertama ( SMP ) Negeri 2 Sidoharjo Kabupaten Sragen Tahun Pelajaran 2014/2015. Skripsi: Univet Bantara Sukoharjo. 
Pita Damayanti. 2013. Meningkatkan Aktivitas Belajar Matematika pada Pecahan dengan Metode Cooperative Learning Tipe Think pair share bagi siswa Kelas V SD Negeri 2 Setrorejo Baturetno Wonogiri Tahun Pelajaran 2012/2013. Skripsi: Univet Bantara Sukoharjo.

Poerwodarminto.2003. Kamus Umum Bahasa Indonesia. Jakarta: Balai Pustaka.

Suprijono, Agus. 2009. Cooperative Learning Teori dan Aplikasi Paikem. Yogyakarta: Pustaka Pelajar. 